\title{
Chapter \\ [12] \\ Sustainable approaches towards wastewater treatment using algal technology along with management of post-harvest biomass
}

\author{
Vinod Kumar1, Richa Kothari², \\ Sonika Kumari, ${ }^{1,2}{ }^{*}$ and Pankaj Kumar ${ }^{1}$
}

\footnotetext{
${ }^{1}$ Agro-ecology and Pollution Research Laboratory, Department of Zoology and Environmental Science, Gurukula Kangri (Deemed to be University), Haridwar 249404, Uttarakhand, India ${ }^{2}$ Department of Environmental Sciences, Central University of Jammu, Samba, Jammu and Kashmir, India
}

Abstract Industries like food processing, pulp, and paper, dairy, poultry, leather, etc. generate a huge amount of wastewater. The generated wastewater has a high toxicity in terms of BOD, COD, TDS, nutrients, heavy metals, carcinogenic pollutants, etc. The discharge of untreated wastewater into water bodies leads to their pollution and eutrophication, which gives rise to algal blooms and ultimately causes harm to the aquatic organisms. The wastewater generated from industries causes harm to many life forms therefore, its treatment before discharge has become an issue of concern. As wastewater contains enough amount of nutrients hence, can be used for algal growth. Algae are autotrophic organisms that require nutrients and sunlight for their growth. Algae provide sustainable means for wastewater treatment. Apart from wastewater treatment, algal biomass can be used in biofuels production, as biofertilizers, $\mathrm{CO}_{2}$ sequestration, and for the production of value-added products. This book chapter deals with algae-based wastewater treatment along with various ways of algal biomass management and how algal biomass can be used as potential bioenergy material.

Keywords

Algal biomass, Bioenergy, Value-added products, Wastewater treatment

Sonika Kumari, Email: sonikakumari02gkv@gmail.com $\left({ }^{*}\right.$ Corresponding author $)$ 


\section{Introduction}

The rapid industrialization around the world has created problems of contaminants and pollutants. Every day, huge amount of wastewater is being produced from different industrial processes globally (Bansal et al., 2018). Discharge of untreated wastewater poses threat to both ecological and human health. Earth has limited freshwater resources that are not being used judicially and either water is being wasted or polluted through waste disposal. Besides this, the increase in the world population has increased pressure on water resources (Wollmann et al., 2019). Shortage in the availability of freshwater for domestic and industrial purposes is a major challenge throughout the world which has raised the concern of developing appropriate wastewater treatment methods (Piao et al., 2016). Various processes can be used to clean wastewater like primary, secondary and tertiary treatment processes, phytoremediation/bioremediation, biosorption, etc. (Lema and Martinez, 2017; Kumar et al., 2020).

Besides all wastewater treatment methods, bioremediation is gaining much more popularity because of its environment-friendly aspect. Bioremediation involves the use of naturally occurring living organisms like algae, bacteria, and plants (aquatic and terrestrial) for removing hazardous pollutants from the environment (Kshirsagar, 2013). In the case of different aspects of bioremediation, the phycoremediation process is the most preferred method. Phycoremediation is the use of algal species for wastewater treatment and has numerous benefits over other conventional remediation techniques including, cost-effectiveness, eco-friendly, low input and maintenance costs, etc. (Wells et al., 2017). Industrial wastewaters contain a high load of organic and inorganic nutrients and therefore, can be used as a culture medium of algae (Simate et al., 2011). Algae are aquatic, eukaryotic organisms that can be microscopic or macroscopic, and cosmopolitan in the distribution in both fresh and marine environments. Algae have a fast growth rate, high lipid content when compared with terrestrial crops and do not compete for land with food crops and also helps in carbon sequestering (Gilbert and Ashraf, 2017).

The algal biomass generated after the phycoremediation has wide utility in the field of bioenergy. The population explosion has increased the energy demands of the world drastically. To meet the global energy demands fossil fuels are being used in direct or indirect ways. The excessive combustion of fossil fuels causes many negative impacts on the environment such as global warming, emission of greenhouse gases, air pollution, acid rain, change in global weather patterns, etc. (Alatraktchi et al., 2014; Lee et al., 2008). As fossil fuels are non-renewable energy sources and are near about their depletion. There is an urgent need to find environmental friendly alternatives to current energy resources (Mathimani et al., 2015; Subsamran et al., 2018). There is a wide variety of renewable and sustainable energy resources like solar energy, biomass, wind energy, hydroelectricity, tidal energy, etc. that can generate clean energy but are less energy-efficient sources (Kabir et al., 2018). Biomass includes organic material such as aquatic plants, algal biomass, agricultural residues, animal, poultry, food 
processing, leather industry, municipal solid wastes, etc. (Alam et al., 2015; Maity et al., 2014; Sims et al., 2010). Out of them, algae are rich in carbohydrates, lipids, proteins, pigments, and act as a good source to produce value-added products, like biodiesel, bioethanol, biogas, biochar, biohydrogen, biobutanol, etc. (Jones and Mayfield, 2012). The exploration of the utilization of algae for the reclamation of a damaged environment presents one of the best methods of its conservation. Keeping in view, this book chapter deals with the integrated approach of wastewater treatment using algae along with different possible methods of their biomass management.

\section{Algal wastewater treatment}

Wastewater refers to liquid wastes generated after a final product is obtained from households, commercial complexes, workshops, and industries like dairy, food processing, textile, leather, pharmaceutical, etc. Wastewater has high pollutant loads (Simate et al., 2011) and the direct discharge of untreated wastewater in water bodies is creating lots of environmental issues especially, water pollution (Cai et al., 2013). Due to its nutrient richness wastewater are often used for growing algae. Algal species are capable of utilizing nutrients from wastewater for its growth and development, therefore, has immense potential for treating wastewater (Bansal et al., 2018). Nowadays, most industries are adopting algal-based wastewater treatment because it is a cost-efficient and eco-friendly technique. Some of the algal species being used in wastewater treatment (Figure 1).

Table 1 shows the various studies on the treatment of different pollutants from wastewaters using various algal species. Recently, numerous studies have been done for the reclamation of different types of wastewaters. Out of them, Valizadeh and Davarpanah (2020) in their parametric study on dairy wastewater treatment using Chlorella vulgaris obtained $42.57 \%$ of COD removal efficiency. Gaughy et al. (2019) through their study on the treatment of wastewater produced from hydrothermally treated septage using Chlorella sp. attained $98 \%$ of ammonia and $50 \%$ of other nutrient removal efficiencies. In another study by Fazal et al. (2017), the potential of various microalgal species for the bioremediation of textile wastewater was assessed. They reported that the microalgae use dyes as a carbon source which are further converted into metabolites, besides other processes microalgal wastewater treatment turned out to be most promising for the treatment of textile wastewater. Another study conducted by Kshirsagar (2013) on bioremediation of domestic wastewater using C. vulgaris and S. quadricauda showed a significant reduction in BOD, COD, nitrates, and phosphates. In a case study conducted by Posadas et al. (2014) on a fish farm and domestic wastewater treatment using algal ponds it was found that a significant amount of nitrogen $(>70 \%)$ and phosphate $(>80 \%)$ removal was achieved.

Furthermore, Higgins et al. (2018) conducted a study on winery wastewater using Auxenochlorella protothecoides and Chlorella sorokiniana which attained more than $90 \%$ of nitrogen, greater than $50 \%$ of phosphate, and $100 \%$ of acetic acid removal. Wang et al. (2010) cultivated Chorella sp. on municipal 
Table 1. Use of different algal species for the treatment of different pollutants from wastewaters.

\begin{tabular}{|c|c|c|c|c|}
\hline Wastewater & Pollutants & Algal species & Removal achieved & Reference \\
\hline $\begin{array}{l}\text { Municipal } \\
\text { wastewater }\end{array}$ & $\begin{array}{l}\text { Phospho- } \\
\text { rus and } \\
\text { COD }\end{array}$ & Chlorella sp. & $\begin{array}{l}83.2 \% \text { - } 90.6 \% \text { phosphorus and } \\
50.9-83.0 \% \text { COD removed }\end{array}$ & $\begin{array}{l}\text { Wang et al. } \\
(2010)\end{array}$ \\
\hline $\begin{array}{l}\text { Piggery } \\
\text { wastewater }\end{array}$ & $\begin{array}{l}\text { TN,TP and } \\
\text { COD }\end{array}$ & $\begin{array}{l}\text { Chlorella } \\
\text { zofingiensis }\end{array}$ & $\begin{array}{l}68.96 \% \text { to } 81.03 \% \text { total nitrogen, } \\
98.17 \% \text { to } 100 \% \text { total } \\
\text { phosphorous, and } 65.81 \% \text { to } 79.84 \\
\% \text { COD removed }\end{array}$ & Zhu et al. (2013) \\
\hline $\begin{array}{l}\text { Primary-settled } \\
\text { wastewater }\end{array}$ & $\begin{array}{l}\text { Biological } \\
\text { pollutants }\end{array}$ & $\begin{array}{l}\text { Galdieria } \\
\text { sulphuraria }\end{array}$ & $\begin{array}{l}98 \% \text { removal of total bacteria and } \\
\text { complete removal of Enterococcus } \\
\text { faecalis and Escherichia coli }\end{array}$ & $\begin{array}{l}\text { Delanka-Pedige } \\
\text { et al. (2019) }\end{array}$ \\
\hline $\begin{array}{l}\text { Domestic } \\
\text { wastewater }\end{array}$ & $\begin{array}{l}\mathrm{TN}, \mathrm{TP} \text { and } \\
\mathrm{COD}\end{array}$ & Algal biofilm & $\begin{array}{l}\mathrm{TN}, \mathrm{TP} \text { and COD removal reached } \\
96.0 \%, 91.5 \% \text { and } 80.2 \% \\
\text { respectively }\end{array}$ & Yang et al. (2018) \\
\hline $\begin{array}{l}\text { Winery } \\
\text { wastewater }\end{array}$ & $\begin{array}{l}\mathrm{TN}, \mathrm{TP} \\
\text { and acetic } \\
\text { acid }\end{array}$ & $\begin{array}{l}\text { Auxenochlorella } \\
\text { protothecoides } \\
\text { and Chlorella } \\
\text { sorokiniana }\end{array}$ & $\begin{array}{l}>90 \% \text { of nitrogen, }>50 \% \text { of phos- } \\
\text { phate, and } 100 \% \text { of acetic acid } \\
\text { removed }\end{array}$ & $\begin{array}{l}\text { Higgins et al. } \\
\text { (2018) }\end{array}$ \\
\hline $\begin{array}{l}\text { Secondarily } \\
\text { treated domestic } \\
\text { wastewater }\end{array}$ & $\begin{array}{l}\text { Ciprofloxa- } \\
\text { cin }\end{array}$ & Mixed & $>84 \pm 9 \%$ removal & $\begin{array}{l}\text { Hom-Diaz et al. } \\
\text { (2017) }\end{array}$ \\
\hline $\begin{array}{l}\text { Dairy } \\
\text { wastewater }\end{array}$ & COD & C. vulgaris & $42.57 \%$ COD removed & $\begin{array}{l}\text { Valizadeh and } \\
\text { Davarpanah } \\
(2020)\end{array}$ \\
\hline $\begin{array}{l}\text { Textile } \\
\text { wastewater }\end{array}$ & COD & $\begin{array}{l}\text { Chlorella } \\
\text { vulgaris }\end{array}$ & $70 \%$ COD removed & $\begin{array}{l}\text { El-Kassas and } \\
\text { Mohammad } \\
(2014)\end{array}$ \\
\hline $\begin{array}{l}\text { Fish farming } \\
\text { wastewater }\end{array}$ & $\mathrm{N}$ and $\mathrm{P}$ & $\begin{array}{l}\text { Microalgal } \\
\text { consortia }\end{array}$ & $\begin{array}{l}83 \pm 10 \% \text { of nitrogen and } 94 \pm 6 \% \\
\text { of phosphates removed }\end{array}$ & $\begin{array}{l}\text { Posadas et al. } \\
\text { (2014) }\end{array}$ \\
\hline $\begin{array}{l}\text { Urban } \\
\text { wastewater }\end{array}$ & $\mathrm{N}$ and $\mathrm{P}$ & $\begin{array}{l}\text { Nannochlo- } \\
\text { ropsis oculata }\end{array}$ & $\begin{array}{l}95 \% \text { of nitrogen and } 98 \% \\
\text { phoshorous removed }\end{array}$ & $\begin{array}{l}\text { Caporgno et al. } \\
(2015)\end{array}$ \\
\hline
\end{tabular}

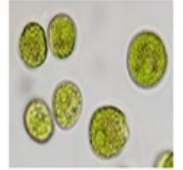

Chlamydomonas sp.

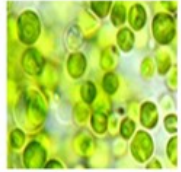

Chlorella sp.

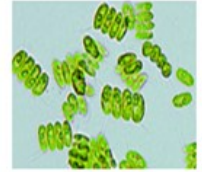

Scenedesmus sp

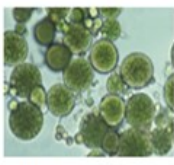

Pediastrum sp.

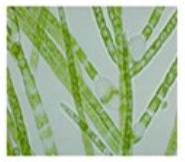

Stigeodonium sp.

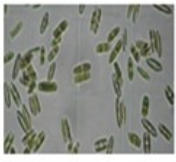

Navicula sp.

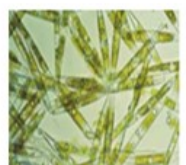

Nitzschia sp.

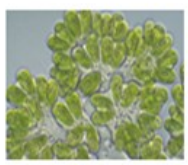

Botryococcus sp.

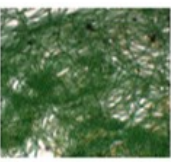

Oscillatoria sp.

Figure 1. Some of the algal species being used in wastewater treatment. 
wastewater for pollutant removal and achieved $83.2 \%$ to $90.6 \%$ phosphorus removal and $50.9 \%$ to 83.0 $\%$ COD reduction.

\section{Post-harvest management of algal biomass}

The algal biomass harvested after the wastewater treatment process can be utilized in different ways (Figure 2). For example, algal biomass can be used to serve the purpose of biofertilizers, biofuels, biochar, etc. Moreover, various food products like nutraceuticals, protein animal feed, and various nutrient supplements can also be produced from waste algal biomass (Mathimani and Pugazhendhi, 2018).

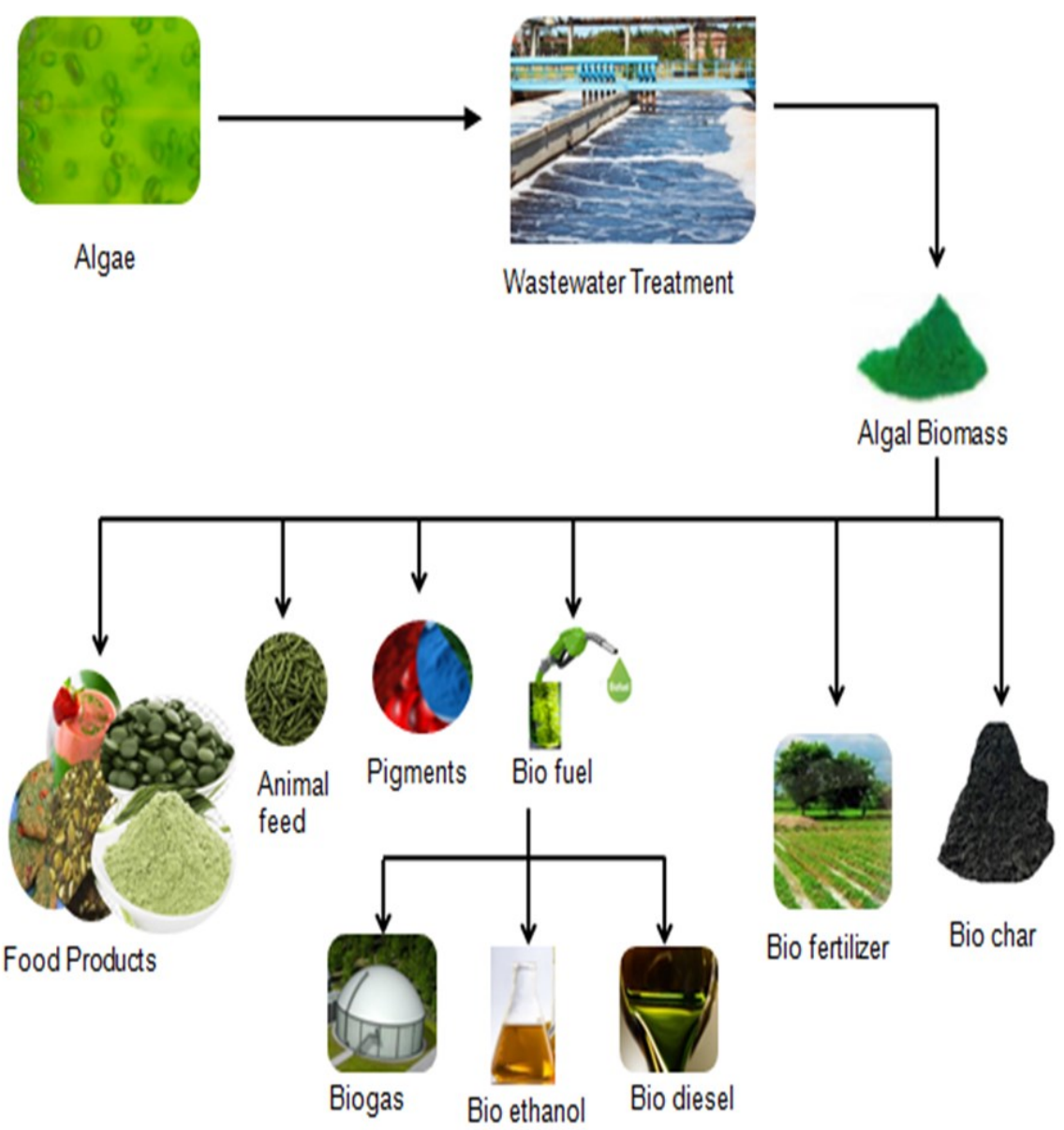

Figure 2. Different methods of algal biomass management. 


\section{Biofuels}

Biofuels are produced from organic or biological wastes like lignocellulosic residues from agricultural, commercial, domestic, and industrial wastes. Biofuels are eco-friendly and pollution-free energy sources, moreover, it helps in reducing net carbon emission (Saad et al., 2019). Algal biomass is also a kind of organic waste and can be used to produce bioethanol, biodiesel, biogas, etc. Several countries like Brazil, Germany, United States, Sweden, and France are the leader in the production and consumption of these biofuels (Adeniyi et al., 2018).

Bioethanol: Algal biomass can also be used to obtain bioethanol through the alcoholic fermentation of carbohydrates. Moreover, algal cellulose and hemicellulose can also be used to obtain bioethanol by converting them to sugars through various pretreatment processes. Fermentation is the conversion of sugars into bioethanol $\left(\mathrm{C}_{2} \mathrm{H}_{5} \mathrm{OH}\right)$. Bioethanol is a high octane fuel, and therefore, can be used as a petrol substitute or blended (10\% to $20 \%$ ) with commercial petrol in transport vehicles (Saad et al., 2019). In a study, Johan et al. (2010) reported the potential of various micro and macroalgal species for bioethanol production using different methods. Another study carried by Jalilian et al. (2019) on biofuel production indicated that Chlorella vulgaris FSP-E can be used as a potential feedstock for the production of bioethanol.

Biodiesel: Biodiesel is a kind of diesel fuel derived from a variety of lipid-containing feedstocks like oil crops (castor, sunflower), food crops (corn, soybean), algae, etc. Using food and oil crops for biodiesel production can lead to food security issues. High lipid content makes algal oil the most suitable feedstock for biodiesel production (Rajkumar et al., 2014). Biodiesel is produced by the trans-esterification of algal bio-oil and can be used as vehicular fuel in pure form or as diesel additive. Marella et al. (2019) through their study showed the biodiesel production potential of algae cultivated on urban wastewater. A study carried by Caporgno et al. (2015) on the cultivation of microalgae C. kessleri and C. vulgaria in urban wastewater for biodiesel and methane production shows biodiesel yield of $7.4 \pm 0.2 \mathrm{~g} / 100 \mathrm{~g}_{\mathrm{vs}}$ and $11.3 \pm 0.1 \mathrm{~g} / 100 \mathrm{~g}_{\mathrm{vs}}$ for C. kessleri and C. vulgaria, respectively. Furthermore, Mata et al. (2009), Gill (2013), and Jayakumar et al. (2017) also studied biodiesel production from various feedstocks (Table 2).

Biogas: The wet algal biomass left after wastewater treatment can be converted into biogas. However, algal biomass has low digestion potential and the addition of activated sludge can help to increase the digestion rate (Dębowski et al., 2013). Organic matter of algal biomass breaks down through anaerobic digestion to produce $\mathrm{CH}_{4}$ and $\mathrm{CO}_{2}$ which are the main constituents of biogas. The biogas produced from algal biomass can be used for generating power by gas engines as well as an energy source for domestic cooking (Gilbert and Ashraf, 2017). Shchegolkova et al. (2018) conducted a study using microalgae for wastewater treatment and biogas production in which significant results were obtained and the biogas produced was composed of 57.0-59.7\% methane and 40.3-43.0\% carbon dioxide. Another study by Xiao et al. (2019) on biogas production from microalgal biomass via anaerobic 
Table 2. Biodiesel production from various feedstocks (Source: Mata et al., 2009; Gill, 2013; Jayakumar et al., 2017).

\begin{tabular}{lll}
\hline Name of crop & Oil yield (L/ha) & Biodiesel production (kg biodiesel/ha-year) \\
\hline Corn & 172 & 152 \\
Soybean & 446 & 562 \\
Canola & 1190 & 862 \\
Sunflower & 1070 & 946 \\
Palm Oil & 5366 & 4747 \\
Jatropha & 741 & 656 \\
Castor & 1307 & 1156 \\
Microalgae (wet biomass) & 58,700 & 51,927 \\
Microalgae (Dry biomass) & 136,900 & 121,104 \\
\hline
\end{tabular}

digestion showed that the highest exergy efficiency ( $40.85 \%)$ was achieved by solar-driven hydrothermal pretreatment followed by biogas production with hydrothermal pretreatment $(35.98 \%)$ and without pretreatment $(26.2 \%)$.

\section{Biofertilizers}

Microorganisms, like, bacteria, fungi, and algae that are capable of degrading organic wastes and complex nutrients to simpler forms, and this final product can be used to enhance soil quality, nutrient transfer, crop growth, and yield which are known as biofertilizers. Algal biomass can also be used as biofertilizers. Blue-green algae are the most commonly used algal group as biofertilizers. Biofertilizers helps in promoting sustainable and organic farming (Castro et al., 2020). In a study conducted by Garcia -Gonzalez and Sommerfeld (2016), the authors investigated the use of Acutodesmus dimorphus extract as a foliar spray application at $3.75 \mathrm{~g} / \mathrm{L}$ for tomato plant resulted in improved plant height, increase in flowering rate, and branches per plant. The Acutodesmus dimorphus extract can be employed as a seed primer at $0.75 \mathrm{gM} / \mathrm{L}$ as it triggered faster seed germination. Ronga et al. (2019) through their study on various microalgal species established the potential of microalgae as a biostimulant and biofertilizer for improving crop productivity and contributing towards agricultural sustainability and reduced environmental impact. Some of the algal species being used as biofertilizers are given in Table 3 .

\section{Biochar}

Biochar is a dark-colored carbon-rich organic substance obtained from the pyrolysis of waste biomass. Biochar can be used as a soil conditioner as it improves soil $\mathrm{pH}$, increases soil carbon and nitrogen exchange rates, and therefore, helps in increasing crop yields (Rizwan et al., 2018). Moreover, biochar can be used as an adsorbent for various treatment processes, as an energy source for the generation of heat and power, and as a carbon sequestration agent (Amin et al., 2016). Algal biomass is an ideal waste for the production of biochar as revealed from recent studies. Yu et al. (2018) from their study on biochar production from Chlorella vulgaris FSP-E suggested that the biochar yield obtained was 21.55 
Table 3. Contribution of various algal species used as biofertilizers (Source: Castro et al., 2020)

\begin{tabular}{|c|c|c|}
\hline Algal class & Name of species & Contribution \\
\hline Blue-green algae & $\begin{array}{l}\text { Nostoc, Anabaena, Aulosira, Tolypothrix, } \\
\text { Nodularia, Cylindrospermum, Scytonema, } \\
\text { Aphanothece, Calothrix, Anabaenopsis, } \\
\text { Mastigocladus. }\end{array}$ & $\begin{array}{l}\text { Produce growth-promoting } \\
\text { substances }\end{array}$ \\
\hline Red macroalgae & $\begin{array}{l}\text { Phymatolithon calcareum, Lithothamnion } \\
\text { corallioides }\end{array}$ & Trace elements \\
\hline Brown macroalgae & $\begin{array}{l}\text { Laminaria digitata, Saccharina latissi- } \\
\text { ma ,Fucus vesiculosus ,Ascophyllum } \\
\text { nodosum,Ecklonia maxima, }\end{array}$ & $\begin{array}{l}\text { Rich in N P, K, } \\
\text { Carbohydrates, enhance plant } \\
\text { growth, drought and salt } \\
\text { tolerance and resistance to fungi, } \\
\text { bacteria, and virus. }\end{array}$ \\
\hline
\end{tabular}

wt $\%$ to $38.4 \mathrm{wt} \%$ The microalgal biochar showed an HHV of $23.42 \mathrm{MJ} / \mathrm{kg}$ and can be used as an alternative to coal for energy production. Through their study on biochar produced from microalgae, $C$. vulgaris Arun et al. (2018) showed the potential of algal biochar as a source for the removal of pollutants from wastewater. In another study, Torri et al. (2011) indicated that about $44 \pm 1 \%$ biochar and $28 \pm 2 \%$ biofuel were obtained from the pyrolysis of the biomass of microalgae Chlamydomonas reinhardtii, and also the obtained biochar was rich in nitrogen content.

\section{Animal feeds}

Due to their high protein, carbohydrate, and oil contents, algae are being used as feed for cows, pigs, cats, dogs, poultry, as well as in fish farming. Using algal nutrition even in small amounts results in an improved immune system, increases egg-laying capacity, growth promotion, and also improves reproductive performance (Madeira et al., 2017). Altomonte et al. (2018) in their study investigated the use of microalgae in ruminant nutrition and concluded that the use of an appropriate amount of microalgae in animal feed can improve omega 3 content in the milk of ruminants. In another study, Shah et al. (2018) explored the potential of microalgae in aquafeed as a supplement or feed additives as algae are a rich source of protein, lipid, pigments, vitamins, etc. Also, the presence of EPA and DHA in microalgae increases the significance of microalgae for its use in aquafeed.

\section{Food products and other supplements}

Algae are a rich source of proteins, vitamins, minerals, polyunsaturated fatty acids, antioxidants, etc., therefore, can be used in making health drinks, cookies/biscuits, protein bars, as thickening agents in ice-creams, marmalade, jellies, etc. (Piwowar and Harasym, 2020). Nowadays, various food supplements are being prepared from microalgal biomass. For example, a protein supplement is available in the market in the form of capsules, tablets, and powder which is derived from microalgae 
Spirulina (Kovač et al., 2013). In their study by Ścieszka and Klewicka (2018), the potential of algae in the food industry in food supplements like dietary supplements and as additives in food products like in marmalade, dairy products, cereal-based products due to their enriched protein, lipid, pigment, vitamin, carbohydrate contents have been reported. Torres-Tiji et al. (2020) from their study suggested that algae have the potential to become a new food crop and with the implementation of the newest genetic engineering tools algae can efficiently meet the world's food and feed demand shortly.

\section{Pigment extraction}

Pigments like chlorophylls, carotenoids, and phycobiliproteins, etc. are responsible for giving beautiful colors to different algal species (Prasanna et al., 2007). Various applications of different algal pigments are given in Table 4. Being non-toxic and eco-friendly, pigments from some algal species can be used for a variety of purposes like natural coloring agent for food products (chewing gum, ice creams, soft drinks, desserts, cakes, milkshakes, etc.) (Suganya et al., 2016). In the pharmaceutical industry, these pigments are widely used as antioxidants, anti-inflammatory, anti-cancer, and anti-allergic materials (Chew et al., 2017). In the cosmetics industry, these pigments are used for giving color to soaps, skin, and hair care products due to their antiageing properties (Wang et al., 2015). Besides this, they can also be used in the textile industry as fabricating and dyeing agents. Huangfu et al. (2013) suggested that astaxanthin pigment obtained from alga Haematococcus pluvialis can extend the life span of fruit flies by complementing with the defective antioxidant defense system of fruit flies. Chakdhar and Pabbi (2017) in their study showed the importance of various algal pigments for improving human health as well as the commercial importance of algal pigments for the cosmetic industry.

\section{Future scope and research recommendations}

Algal species are rich in various colored pigments that are being used in various food products, cosmetics, and medicines but still there is much more in the field of algal pigments, the full potential of algal biomass concerning algal pigment is yet to be explored. Although algal biomass is widely being used for the production of biogas the complete biogas production potential of algal biomass has still not

Table 4. Applications of various algal pigments (Source: Li et al., 2019).

\begin{tabular}{lll}
\hline Algae & Pigment & Applications \\
\hline $\begin{array}{l}\text { Mutants of Dunaliella } \\
\text { Dunaliella sp. }\end{array}$ & Lutein & Food colorant, antioxidant \\
& Carotenoids & $\begin{array}{l}\text { Food colorant, pro vitamin-A, } \\
\text { bioactive compound }\end{array}$ \\
Chorella, Spirulina & Chlorophyll & Cosmetics, antioxidant \\
Haematococcus sp. & Astaxanthin & Cosmetics, food colorant \\
Spirulina sp. & Phycocyanin & Diagnostic agent, bioactive com- \\
& & pound (anti cancer), cosmetics \\
Porphyridium purpureum & Phycoerythrin & Cosmetics, food colorant \\
\hline
\end{tabular}


reached its full potential, the addition of suitable microorganisms can improve the biogas production potential of algal biomass. Phycoremediation has emerged as the most promising technique of wastewater treatment but genetic engineering can be applied to phycoremediation to improve its remediation efficiency. Algal biomass can be used in the synthesis of metal oxide nanoparticles which can provide an eco-friendly alternative to the toxic chemicals which are commonly used in the synthesis of metal oxide nanoparticles. Hybrid cultivation of algal biomass can be adapted which includes both open and closed pond systems as it can produce high biomass along with a reduction in contamination. The microalgae can be cultivated in membrane photobioreactors, it can reduce the requirement of dewatering. Besides this more exploration of potential of algal species can be done.

\section{Conclusion}

The discharge of untreated industrial wastewater causes serious environmental problems such as soil and water pollution. However, industrial wastewaters are rich in several nutrients so, can be used to grow algae. Therefore, algal species have great potential in wastewater treatment. Thus, this book chapter emphasizes the role of algal biomass after phycoremediation of wastewater, can be used as a good resource for bioenergy production and other value-added products. Algal based wastewater treatment is an eco-friendly and cost-efficient approach and serves dual approaches of environmental sustainability.

Conflict of interest: The author declares that there is no conflict of interest.

\section{Acknowledgments}

This work was academically supported by the Department of Zoology and Environmental Science, Gurukula Kangri (Deemed to be University), Haridwar, Uttarakhand, India, and the Department of Environmental Sciences, Central University of Jammu, Samba, Jammu and Kashmir, India. The Corresponding author (S. K.) is grateful to the lab mates for their support and guidance at each step.

\section{References}

Adeniyi, O.M., Azimov, U. and Burluka, A. (2018). Algae biofuel: Current status and future applications. Renewable and Sustainable Energy Reviews, 90: 316-335, https://doi.org/10.1016/j.rser.2018.03.067

Alam, F., Mobin, S. and Chowdhury, H. (2015). Third generation biofuel from algae. Procedia Engineering, 105: 763-768.

Alatraktchi, F.A.A., Zhang, Y. and Angelidaki, I. (2014). Nanomodification of the electrodes in microbial fuel cell: impact of nanoparticle density on electricity production and microbial community. Applied Energy, 116: 216-22, https://doi.org/10.1016/j.apenergy.2013.11.058

Altomonte, I., Salari, F., Licitra, R. and Martini, M. (2018). Use of microalgae in ruminant nutrition and implications on milk quality - A review. Livestock Science, 214: 25-35. 
Amin, F.R., Huang, Y., He, Y., Zhang, R., Liu, G. and Chen, C. (2016). Biochar applications and modern techniques for characterization. Clean Technologies and Environmental Policy, 18(5): 1457-1473.

Arun, J., Varshini, P., Prithvinath, P.K., Priyadarshini, V. and Gopinath, K.P. (2018). Enrichment of bio-oil after hydrothermal liquefaction (HTL) of microalgae C. vulgaris grown in wastewater: bio-char and post HTL wastewater utilization studies, Bioresource Technology , 1-28, https://doi.org/10.1016/j.biortech.2018.04.029

Bansal, A., Shinde, O. and Sarkar, S. (2018). Industrial wastewater treatment using phycoremediation technologies and coproduction of value-added products. Journal of Bioremediation and Biodegradation, 9(1): 1-10, https://doi.org/10.4172/21556199.1000428

Cai, T., Park, S.Y. and Li, Y. (2013). Nutrient recovery from wastewater streams by microalgae: status and prospects. Renewable and Sustainable Energy Reviews, 19: 360-369, https://doi.org/10.1016/j.rser.2012.11.030

Caporgno, M.P., Taleb, A., Olkiewicz, M., Font, J., Pruvost, J., Legrand, J. and Bengoa C. (2015). Microalgae cultivation in urban wastewater: nutrient removal and biomass production for biodiesel and methane. Algal Research, 10: 232-239, https://doi.org/10.1016/j.algal.2015.05.011

Castro, J.S., Calijuri, M.L., Ferreira, J., Assemany, P.P. and Ribeiro, V.J. (2020). Microalgae based biofertilizer: A life cycle approach. Science of The Total Environment, 1-10, https://doi.org/10.1016/j.scitotenv.2020.138138

Chakdar, H. and Pabbi, S. (2017). Algal pigments for human health and cosmeceuticals. Algal Green Chemistry, 171-188, http:// doi.org/10.1016/B978-0-444-63784-0.00009-6

Chew, K.W., Yap, J.Y., Show, P.L., Suan, N.H., Juan, J.C., Ling, T.C., Lee, D.J. and Chang, J.S. (2017). Microalgae biorefinery: high value products perspectives. Bioresource Technology, 229: 53-62, https://doi.org/10.1016/j.biortech.2017.01.006

Delanka-Pedige, H.M., Munasinghe-Arachchige, S.P., Cornelius, J., Henkanatte-Gedera, S.M., Tchinda, D., Zhang, Y. and Nirmalakhandan, N. (2019). Pathogen reduction in an algal-based wastewater treatment system employing Galdieria sulphuraria. Algal Research, 39: 1-6, https://doi.org/10.1016/j.algal.2019.101423

El-Kassas, H.Y. and Mohamed, L.A. (2014). Bioremediation of the textile waste effluent by Chlorella vulgaris. Egyptian Journal of Aquatic Resource, 40: 301-308.

Fazal,T., Mushtaq, A., Rehman, F., Khan, A.U., Rashid, N., Farooqc, W., Rehman, M.S.U. and Xud, J. (2017). Bioremediation of textile wastewater and successive biodiesel production using microalgae. Renewable and Sustainable Energy Reviews, 1-20, http://dx.doi.org/10.1016/j.rser.2017.10.029

Garcia-Gonzalez, J. and Sommerfeld, M. (2016). Biofertiliser and biostimulant properties of the microalga Acutodesmus dimorphus. Journal of Applied Phycology, 28: 1051-1061.

Gaughy, M.K., Ahmad Abu Hajer, A.A., Drabold, E., Bayless, D. and Reza, M.T. (2019). Algal remediation of wastewater produced from hydrothermally treated septage. Sustainability, 11:1-8, https://doi.org/10.3390/su11123454

Gilbert, R. and Ashraf, M.A. (2017). Microalgae: a potential plant for energy production. Geology, Ecology, and Landscapes, 1(2): 104-120, https://doi.org/10.1080/24749508.2017.1332853

Gill. (2013). Pakistan journal of life and social sciences waste-water treatment coupled with biodiesel production using microalgae: a bio-refinery approach. Pakistan Journal of Life Social Science, 11: 179-89.

Higgins, B.T., Gennity, I., Fitzgerald, P.S., Ceballos, S.J., Fiehn, O. and VanderGheynst, J.S. (2018). Algal-bacterial synergy in treatment of winery wastewater. Nature Partner Journals Clean Water, 1(1): 1-10, https://doi.org /10.1038/s41545-018-0005-y

Hom-Diaz, A., Norvill, Z.N., Blánquez, P., Vicent, T. and Guieysse, B. (2017). Ciprofloxacin removal during secondary domestic wastewater treatment in high rate algal ponds. Chemosphere, 180:33-41, https://doi.org/10.1016/j.livsci.2018.05.006

Huangfu, J., Liu, J., Sun, Z., Wang, M., Jiang, Y., Chen, Z.Y. and Chen, F. (2013). Antiagingeffects of astaxanthin-rich alga Haematococcus pluvialis on fruit flies under oxidative stress, Journal of Agricultural and Food Chemistry, 61(32): 7800-7804, 
https://doi.org/10.1021/jf402224w

Jalilian, N., Najafpour, G.D. and Khajouei, M. (2019). Macro and micro algae in pollution control and biofuel production - a review. ChemBioEng Reviews, 7: 1-17, https://doi.org/10.1002/cben.201900014

Jayakumar, S., Yusoff, M.M., Rahim, M.H.A., Maniam, G.P. and Govindan, N. (2017). The prospect of microalgal biodiesel using agro-industrial and industrial wastes in Malaysia. Renewable and Sustainable Energy Reviews, 72: 33-47, http://doi.org/10.1016/j.rser.2017.01.002

John, R.P., Anisha, G.S., Nampoothiri, K.M. and Pandey, A. (2010). Micro and macroalgal biomass: a renewable source for bioethanol. Bioresource Technology, 102: 186-193, https://doi.org/10.1016/j.biortech.2010.06.139

Jones, C.S. and Mayfield, S.P. (2012). Algae biofuels: versatility for the future of bioenergy. Current Opinion in Biotechnology, 23: 346-351, https://doi.org/10.1016/j.copbio.2011.10.013

Kabir, E., Kumar, P., Kumar, S., Adelodun, A.A. and Kim, K.H. (2018). Solar energy: potential and future prospects. Renewable and Sustainable Energy Reviews, 82: 894-900, https://doi.org/10.1016/j.rser.2017.09.094

Kovač, D.J., Simeunović, J.B., Babić, O.B., Mišan, A.C. and Milovanović, I.L. (2013). Algae in food and feed. Food and Feed Research, 40(1): 21-32.

Kshirsagar, A.D. (2013). Bioremediation of wastewater by using microalgae: an experimental study. International Journal of Life Sciences Biotechnology and Pharma Research, 2(3): 1-8.

Kumar, P., Kumar, V., Kumar, S., Singh, J. and Kumar, P. (2020). Bioethanol production from sesame (Sesamum indicum L.) plant residue by combined physical, microbial and chemical pretreatments. Bioresource Technology, 297: 122484.

Lee, H.S., Parameswaran, .P, Kato-Marcus, A., Torres, C.I. and Rittmann, B.E. (2008). Evaluation of energy-conversion efficiencies in microbial fuel cells (MFCs) utilizing fermentable and non-fermentable substrates. Water Resource, 42(6-7): 1501-1510, https://doi.org/10.1016/j.watres.2007.10.036

Lema, J.M. and Martinez, S.S. (2017). Innovative wastewater treatment \& resource recovery technologies: impacts on energy, Economy and Environment, IWA Publishing.

Li, S., Zhao, S., Yan, S., Qiu, Y., Song, C., Li, Y. and Kitamura, Y. (2019). Food processing wastewater purification by microalgae cultivation associated with high value-added compounds production-a review. Chinese Journal of Chemical Engineering, 22(7): 1-66, https://doi.org/10.1016/j.cjche.2019.03.028

Madeira, M.S., Cardoso, C., Lopes, P.A., Coelho, D., Afonso,C., Bandarra, M.N. and Prates, J.A.M. (2017). Microalgae as feed ingredients for livestock production and meat quality: a review. Livestock Science, 203: 1-140, http://doi.org/10.1016/j.livsci.2017.09.020

Maity, J.P., Bundschuh, J., Chen, C.Y. and Bhattacharya, P. (2014). Microalgae for third generation biofuel production, mitigation of greenhouse gas emissions and wastewater treatment: Present and future perspectives-a mini review. Energy, 78: 104-113, https://doi.org/10.1016/j.energy.2014.04.003

Marcin, D., Marcin, Z., Anna, G. and Magda, D. (2013). Algae biomass as an alternative substrate in biogas production technologies-review. Renewable and Sustainable Energy Reviews, 27: 596-604, https://doi.org/10.1016/j.rser.2013.07.029

Marella, T.K., Datta, A., Patil, M.D., Dixit, S. and Tiwari, A. (2019). Biodiesel production through algal cultivation in urban wastewater using algal floway. Bioresource Technology, 280: 222-228, https://doi.org/10.1016/j.biortech.2019.02.031

Mata, T.M., Martins, A.A. and Caetano, N.S. (2010). Microalgae for biodiesel production and other applications: a review. Renewable and Sustainable Energy Reviews, 14: 217-32, http://doi.org/10.1016/j.rser.2009.07.020

Mathimani, T., Uma, L. and Prabaharan, D. (2015). Homogeneous acid catalysed transesterification of marine microalga Chlorella sp. BDUG 91771 lipid-an efficient biodiesel yield and its characterization. Renewable Energy, 81: 523-533, https://doi.org/10.1016/j.renene.2015.03.059

Mathimani, T. and Pugazhendhi, A. (2018). Utilization of algae for biofuel, bio-products and bio-remediation. Biocatalysis and Agricultural Biotechnology, 1-18, https://doi.org/10.1016/j.bcab.2018.12.007 
Mobin, S. and Alam, F. (2017). Some promising microalgal species for commercial applications: a review. Energy Procedia, 110: 510-517, https://doi.org/10.1016/j.egypro.2017.03.177

Piao. W., Kim, Y., Kim, H., Kim. M. and Kim, C. (2016). Life cycle assessment and economic efficiency analysis of integrated management of wastewater treatment plants. Journal of Cleaner Production, 113: 325-337, https://doi.org/10.1016/ j.jclepro.2015.11.012

Piwowar, A. and Harasym, J. (2020). The importance and prospects of the use of algae in agribusiness. Sustainability, 12: 1-13, https://doi.org/10.3390/su12145669

Posadas, E., Mu noz A., García-González, M.C., Muñoz, R. and García-Encina, P. A. (2014). A case study of a pilot high rate algal pond for the treatment of fish farm and domestic wastewaters. Journal of Chemical Technology and Biotechnology, 90: 1094-1101, https://doi.org/10.1002/jctb.4417

Prasanna, R., Sood, A., Suresh, A., Nayak, S. and Kaushik, B. D. (2007). Potentials and applicationsof algal pigments in biology and industry, Acta Botanica Hungarica, 49(1): 131-156, https://doi.org/10.1556/ABot.49.2007.1-2.14

Pulz, O. and Gross, W. (2004). Valuable products from biotechnology of microalgae. Applied Microbiology and Biotechnology, 65: 635-648, https://doi.org/10.1007/s00253-004-1647-x

Rajkumar, R., Yaakob, Z. and Takri, M.S. (2014). Potential of the micro and macro algae for biofuel production: a brief review. BioResources, 9(1): 1606-1633, https://doi.org/10.15376/biores.9.1.1606-1633

Rizwan, M., Mujtaba, G., Memon, S.A., Lee, K. and Rashid, N. (2018). Exploring the potential of microalgae for new biotechnology applications and beyond: a review. Renewable and Sustainable Energy Reviews, 92: 394-404.

Ronga, D., Biazzi, E., Parati, K., Carminati, D., Carminati, E. and Tava, A. (2019). Microalgal biostimulants and biofertilisers in crop productions. Agronomy, 9(192): 1-22, https://doi.org/10.3390/agronomy9040192

Saad, M.G., Dosoky, N.S., Zoromba, M.S. and Shafik, H.M. (2019). Algal Biofuels: current status and key challenges. Energies, 12:1-22, https://doi.org /10.3390/en12101920

Ścieszka, S. and Klewicka, E. (2018). Algae in food: a general review. Critical Reviews in Food Science and Nutrition, 59(21): 124, https://doi.org/10.1080/10408398.2018.1496319

Semite, S., Culet, J., Like, S., Musapatika, E., Ndlovu, S., Walubita, L. and Alvarez, A. (2011). The treatment of brewery wastewater for reuse : state of the art. Department of Civil Engineering, Colombia.

Shah, M.R., Lutzu, G.A., Alam, A., Sarker, P., Chowdhury, M.A.K., Parsaeimehr, A., Liang, Y. and Daroch, M. (2018). Microalgae in aquafeeds for a sustainable aquaculture industry. Journal of Applied Phycology, 30: 197-213, https://doi.org/10.1007/s10811-017-1234-z

Shchegolkova, N., Shurshin, K., Pogosyan, S., Voronova, E., Matorin, D. and Karyakin, D. (2018). Microalgae cultivation for wastewater treatment and biogas production at Moscow wastewater treatment plant. Water Science and Technology, 1-12, https://doi.org/10.2166/wst.2018.088

Sims, R.E., Mabee, W., Saddler, J.N. and Taylor, M. (2010). An overview of second generation biofuel technologies. Bioresource Technology, 101: 1570-1580, https://doi.org/10.1016/j.biortech.2009.11.046

Subsamran, K., Mahakhan, P., Vichitphan, K., Vichitphan, S. and Sawaengkaew, J. (2018). Potential use of vetiver grass for cellulolytic enzyme production and bioethanol production. Biocatalyst and Agriculture Biotechnology. https://doi.org/10.1016/j.bcab.2018.11.023

Suganya, T., Varman, M., Masjuki, H. and Renganathan, S. (2016). Macroalgae and microalgae as a potential source for commercial applications along with biofuels production: a biorefinery approach. Renewable and Sustainable Energy Reviews, 55: 909-941, https://doi.org/10.1016/j.rser.2015.11.026

Torres-Tiji,Y., Fields, F.J. and Mayfield, S.P. (2020). Microalgae as a future food source. Biotechnology Advances, 41: 1-13, https://doi.org/10.1016/j.biotechadv.2020.107536

Torri, C., Samorì, C., Adamiano, A., Fabbri, D., Faraloni, C. and Torzillo, G. (2011). Preliminary investigation on the 
production of fuels and bio-char from Chlamydomonas reinhardtii biomass residue after bio-hydrogen production. Bioresource Technology, 102: 8707-8713, https://doi.org/10.1016/j.biortech.2011.01.064

Valizadeh, K. and Davarpanah, A. (2020). Design and construction of a micro-photo bioreactor in order to dairy wastewater treatment by micro-algae: parametric study. Energy Sources, Part A: Recovery, Utilization, and Environmental Effects, 42(5): 611-624.

Wang, H.M.D., Chen, C.C., Huynh, P. and Chang, J.S. (2015). Exploring the potential of using algae in cosmetics. Bioresource Technology, 184: 355-362, https://doi.org/10.1016/j.biortech.2014.12.001

Wang, J., Wang, X.D., Zhao, X.Y., Liu, X., Dong, T. and Wu, F.A. (2015). From microalgae oil to produce novel structured triacylglycerols enriched with unsaturated fatty acids. Bioresource Technology, 184: 405-414, https://doi.org/10.1016/j.biortech.2014.09.133

Wang, L., Min, M., Li, Y., Chen, P., Chen, Y., Liu, Y., Wang, Y. and Ruan, R. (2010). Cultivation of green algae Chlorella sp. in different wastewaters from municipal wastewater treatment plant. Applied Biochemistry and Biotechnology, 162(4): 1-13, https://doi.org/10.1007/s12010-009-8866-7

Wells, M.L., Potin, P., Craigie, J.S., Raven, J.A., Merchant, S.S., Helliwell, K.E., Smith, A.G., Camire, M.E. and Brawley, S.H. (2017). Algae as nutritional and functional food sources: revisiting our understanding. Journal of Applied Phycology, 29: 949-982, https://doi.org/10.1007/s10811-016-0974-5

Winwood, R.J. (2013). Recent developments in the commercial production of DHA and EPA rich oils from micro-algae. OCL, 20, D604.

Wollmann, F., Dietze, S., Ackermann, J.U., Bley, T., Walther, T., Steingroewer, J. and Krujatz, F.(2019). Microalgae wastewater treatment: biological and technological approaches. Engineering in Life Sciences, 1-12, https://doi.org/10.1002/elsc.201900071

Xiao, C., Liao, Q., Fu, Q., Huang, Y., Xia, A., Shen, W., Chen, H. and Zhu, X. (2019). Exergy analyses of biogas production from microalgae biomass via anaerobic digestion. Bioresource Technology, 289: 1-8, https://doi.org/10.1016/j.biortech.2019.121709

Yang, Z., Pei, H., Hou, Q., Jiang, L., Zhang, L. and Nie, C. (2018). Algal biofilm-assisted microbial fuel cell to enhance domestic wastewater treatment: nutrient, organics removal and bioenergy production. Chemical Engineering Journal, 332: 277-285.

Yu, K.L., Show, P.L., Ong, H.C., Ling, T.C., Chen, W.H. and Salleh, M.A.M. (2018). Biochar production from microalgae cultivation through pyrolysis as a sustainable carbon sequestration and biorefinery approach. Clean Technologies and Environmental Policy, 1-9, https://doi.org/10.1007/s10098-018-1521-7

Zhu, L., Wang, Z., Shu, Q., Takala, J., Hiltunen, E., Feng, P. and Yuan, Z. (2013). Nutrient removal and biodiesel production by integration of freshwater algae cultivation with piggery wastewater treatment. Water Research, 47(13): 4294-4302, http://dx.doi.org/10.1016/j.watres.2013.05.004

$* * * * *$

Cite this chapter as: Kumar, V., Kothari, R., Kumari, S. and Kumar, P. (2020). Sustainable approaches towards wastewater treatment using algal technology along with management of post-harvest biomass. In: Advances in Environmental Pollution Management: Wastewater Impacts and Treatment Technologies, Volume 1, Eds. Kumar, V., Kamboj, N., Payum, T., Singh, J. and Kumar, P., pp. 174-187, https://doi.org/10.26832/aesa-2020-aepm-012 